\title{
Entremés de los labradores y soldados castellanos (I64I): los tercios felipistas en la Cataluña de la Guerra dels Segadors
}

Este ensayo analiza el Entremés de los labradores y soldados castellanos, con un bayle al uso de Cathalunya (I64I), único entremés bilingüe sobre la Guerra dels Segadors que se conserva. Sorprende que un texto de tal valor histórico no se haya estudiado previamente. Acaso las razones del silenciamiento son, por un lado, el hecho de ser bilingüe y, por otro lado, su falta de autoría. Trataré estas dos razones o asuntos y, asimismo, examinaré el carácter panfletario del entremés. Concretamente, estudiaré las descripciones estereotipadas tanto de castellanos como de catalanes que el autor anónimo incorpora en su obra.

Palabras clave: Castilla, Cataluña, entremés, Entremés de los labradores y soldados castellanos, Guerra dels Segadors

This essay analyzes the Entremés de los labradores y soldados castellanos, con un bayle al uso de Cathalunya (I64I), a short and unique bilingual play on the War of the Reapers or Revolt of the Catalans. It is surprising that a text of such historical value has not been previously studied. Perhaps the reasons for the silence are, on the one hand, its bilingualism and, on the other, its lack of authorship. I will focus on these two reasons or issues and, likewise, examine the pamphlet form of the brief play. Specifically, I will study the stereotyped descriptions of both Castilians and Catalans that the anonymous author incorporates into his work.

Keywords: Castile, Catalonia, brief play, Entremés de los labradores y soldados castellanos, War of the Reapers

Guerra de Papeles, Guerra de la Pluma y Guerra de la Tinta son algunos de los nombres que ha recibido la Guerra de Cataluña o la Guerra dels Segadors, una guerra en la que el papel impreso sirve como arma para combatir al enemigo y que, asimismo, convierte el conflicto de I640 a I652 en una guerra moderna a escala internacional. Castilla y Cataluña no solo ponen en marcha una maquinaria armada, sino que también emprenden una maquinaria 
propagandística e ideológica. Durante los doce años de guerra se escribieron numerosos discursos, relaciones, sermones, pregones, avisos, cartas, canciones y poemas en catalán y en castellano. La Proclamación Católica a la Magestad Piadosa de Filipe el Grande (I640) - memorial de agravios escrito en castellano y enviado por los consellers a Madrid - del fraile agustino Gaspar Sala i Berart (1605-70) inaugura la batalla propagandística. ${ }^{\mathrm{I}}$ Francisco de Rioja (1583-1659) se encargará de contestar el memorial de agravios con el Aristarco o censura de la Proclamación Católica de los catalanes (I64I). ${ }^{2}$ Continuarán la batalla propagandística Francisco de Quevedo (1580-I645) y Alexandre de Ros (1598-I656), partidarios del bando felipista, 3 y Francesc Martí i Viladamor (I6ı-89) y Josep Font (siglo XVII), partidarios del bando catalán,4 entre otros. A los tratados filosóficos, teológicos y políticos de los autores anteriores se agregarán panfletos más asequibles a un público popular.5

Dentro del teatro profano durante los años de la guerra también se distinguen dos tipos: el teatro culto de Francesc Fontanella (circa I622-83) ${ }^{6}$ y la obra anónima de carácter histórico titulada La famosa comedia de la entrada del marqués de los Vélez en Cathaluña, rota de las tropas castellanas $y$ assalto de Montjuïc (I64I).7 Albert Rossich considera La comedia del marqués de los Vélez la cruz del teatro fontanellense ("El teatre barroc" 72), tanto por la lengua - Fontanella escribe en catalán y el autor anónimo más en castellano que en catalán - como por su finalidad-Amor, firmesa i porfia ${ }^{8}$ se escribiría para ser representada ante un público distinguido, y $L a$ comedia del marqués de los Vélez para ser leída por un público general. ${ }^{9}$ Ambas tienen más en común de lo que se podría advertir en un primer momento. Las dos están conectadas por la misma acción bélica y, sobre todo, constituyen espectáculos completos. Amor, firmesa i porfia es una tragicomedia en tres actos, acompañada de una loa, de un entremés y de un baile. El conjunto dramático del autor anónimo también se compone de una comedia en tres actos, una loa, un entremés y un baile.

En este ensayo dejo de lado La comedia del marqués de los Vélez y la Loa de la comedia de Montjuïc (I64I), ${ }^{\mathrm{I}}$ y analizo el Entremés de los labradores y soldados castellanos, con un bayle al uso de Cathalunya (164I) (ejemplar de la Biblioteca Museu Víctor Balaguer, ms. XVII/4I/19)."II Esta pieza dramática breve es el único entremés bilingüe de la Guerra dels Segadors que se conserva, y sorprende que un texto de tal valor histórico no se haya estudiado previamente. Acaso las razones del abandono o del silenciamiento son, por un lado, el hecho de ser bilingüe - no pertenece ni a la literatura escrita en catalán ni a la literatura castellana - y, por otro, su falta de autoría. Trataré estos dos asuntos en las páginas siguientes y, asimismo, examinaré el carácter panfletario del entremés. Concretamente, 
estudiaré las descripciones estereotipadas tanto de castellanos como de catalanes que el autor anónimo incorpora en su obra. Con todo, y antes de comenzar el análisis de la conexión entre La comedia del marqués de los Vélez y la Loa de la comedia de Montjuïc, destacaré las características básicas del entremés, y resumiré su trama brevemente.

A diferencia de la comedia y de la loa, en las que predomina el castellano, el entremés es bilingüe. Los labradores catalanes hablan más que los soldados castellanos y, por lo tanto, en la obra domina el catalán. El Entremés de los labradores y soldados castellanos sigue el estilo de los entremeses castellanos de la época, tal y como los define el Diccionario de autoridades: "Representación breve, jocosa y burlesca, la cual se entremete de ordinario entre una jornada y otra de la comedia, para mayor variedad, o para divertir y alegrar al auditorio" ("Entremés" 519 ). Como se observa en el título, Entremés de los labradores y soldados castellanos, los protagonistas pertenecen a dos grupos opuestos: los catalanes son labradores y los castellanos son soldados del rey. El entremés comienza con Traguillos, soldado castellano alojado en la modesta casa del campesino catalán Torner. Es hora de cenar y el soldado se queja de la comida que se le sirve. Traguillos y Torner se pelean entre sí: el castellano desenvaina una espada y el catalán lo amenaza con una pistola. Traguillos abandona la casa, pero Torner sabe que regresará con un grupo de soldados. En consecuencia, Torner le pide a su esposa Dominga que avise a otros labradores - Perot, Escolà y Serra para que lo ayuden. Cuando llegan los tres labradores, se esconden en la casa. Tal como Torner había previsto, Traguillos vuelve con tres soldados castellanos y amenazan al labrador. Es entonces cuando los labradores salen de su escondite con pistolas y un plato con cuernos. Traguillos es obligado a ponerse los cuernos en la frente para mofarse de él. El entremés concluye con una sardana - danza a la que alude la segunda parte del título: con un bayle al uso de Cathalunya - y con Traguillos con los cuernos puestos.

Rossich afirma que La comedia del marqués de los Vélez se imprimió dos veces, y en una de ellas se incorpora la loa - Loa de la comedia de Montjuïcy el entremés - Entremés de los labradores y soldados castellanos - ("El teatre barroc" 72). Concuerdo con Rossich en que las tres piezas van unidas. Me atrevo a afirmar que las tres pertenecen al mismo autor por las razones que expongo a continuación. Primero: las tres juntas forman lo que José María Díez Borque ha llamado "complementariedad" del espectáculo total (Sociedad y teatro 277). Segundo: comedia, loa y entremés son anónimos. Tercero: tratan el mismo tema y son las únicas obras dramáticas que se conservan sobre la guerra. Cuarto: en las tres piezas, el autor demuestra un conocimiento exhaustivo de la historia de Cataluña y de los sucesos que ocurren durante los primeros años de la guerra. Además, las tres siguen un 
mismo estilo, en el que se destaca la ferviente defensa por parte de los catalanes y su constante odio hacia los castellanos. ${ }^{\text {I2 }}$ Quinto: tanto la comedia como el entremés están escritos en castellano y en catalán. En cambio, la loa está escrita en castellano. Aunque en el entremés hay más catalán que en la comedia, se pasa de una lengua a otra con facilidad. En el entremés se utiliza más el catalán porque extrañaría que los labradores no hablaran entre sí en su lengua. Sin embargo, los soldados se expresan en castellano, como también es natural. Aunque la comedia y la loa están redactadas principalmente en castellano, no parece que la razón sea un mayor dominio del castellano por parte del dramaturgo, sino más bien el deseo de una mayor difusión. Conecto el uso de la lengua castellana con el carácter informativo de las tres obras. El autor anónimo está interesado en que castellanos y catalanes observen, a través de su teatro, la crueldad castellana y la valentía catalana. Tampoco descarta la posibilidad de que la obra - o mejor dicho, el manuscrito de la obra - llegue a "Reinos estraños ... en particular ... la Corona de España" (La famosa comedia, fol. 2v). De la misma manera que Sala i Berart y Martí i Viladamor escriben en castellano para comunicar su descontento con la Corte, el autor anónimo anuncia su descontento a un público variado, catalán y castellano, a través del género dramático.

En la comedia, las partes informativas se escriben íntegramente en castellano. En cambio, el catalán se destina a los personajes ficticios y a las descripciones de lo que se considera propiamente catalán. Por ejemplo: la lección de lengua catalana de la criada Aminta a un criado castellano y, ${ }^{13}$ también, la valentía demostrada por un almogávar.14 El parlamento del almogávar muestra la separación de las dos lenguas: por un lado, el contenido descriptivo es en catalán; por otro lado, el contenido informativo es en castellano:

Jo señor os contaré, y no serà de temor, perquè no sé què cosa és, y vull dir-ho en castellà, que per mos pecats en sé. El que govierna las tropas de la ilustre Cathaluña en la campaña que pides, y que tus daños anuncia, es el oidor Ferran. (vv. I458-67, énfasis añadido) 
[Yo señor os contaré,

y no será de temor,

porque no sé qué cosa es,

y quiero decirlo en castellano,

que por mis pecados lo sé.]15

Así pues, el motivo del uso del castellano por parte del almogávar personaje que narra la resistencia de los catalanes en la localidad de Martorell - parece ser el mismo del autor anónimo: informar. Dramaturgo y personaje comparten el anonimato; no se conoce el nombre de ninguno de los dos; hablan catalán y castellano; y escogen la lengua castellana para divulgar los acontecimientos que suceden en Cataluña. El carácter informativo es incluso más patente en la loa, donde no se incluyen personajes ficticios: ahí los dos únicos personajes son alegóricos. Pese a que la loa no tiene nada de objetiva y es propagandística, la ficción aquí no tiene cabida. Por lo tanto, la loa no incorpora la lengua catalana, y Cataluña y Castilla - los personajes alegóricos - dialogan solamente en castellano. En el entremés también hay un detalle que corrobora la hipótesis de que el castellano se utiliza para informar: el título y las didascalias no son en catalán. Aunque parezca poco realista, el autor pudo haber tenido la esperanza de que su obra se leyera e, incluso, se representara fuera de Cataluña. De esta forma, escribe el título y las indicaciones para la puesta en escena en castellano.

Las comedias del siglo XVII en Cataluña "es fan sobretot en castellà, i els entremesos, més efímers i secundaris, en català" ("se hacen sobre todo en castellano, y los entremeses, más efímeros y secundarios, en catalán"; Rossich, "El teatre barroc" 59). En general, los entremeses son más populares y humorísticos, comparados con las comedias, y tiene sentido que los personajes hablen en su propia lengua. Por consiguiente, los labradores, Torner, Perot, Escolà y Serra hablan en catalán. No obstante, no considero que el uso del catalán sea solo por el hecho de que el Entremés de los labradores y soldados castellanos sea una pieza breve o secundaria. Insisto en que el propósito principal del autor anónimo es informar a un público amplio, y con el uso del castellano este público aumenta. El autor anónimo incluye elementos ficticios y episodios humorísticos y es, entonces, cuando utiliza la lengua catalana.

Además de dominar la lengua, el autor anónimo conoce la literatura catalana o, por lo menos, conoce la poesía de Francesc Vicent Garcia (circa 1579-I623), Rector de Vallfogona, a quien considera un visionario. El prólogo de La comedia del marqués de los Vélez finaliza con dos de sus décimas sacadas del poema "Desengany del món". El dramaturgo también está al 
corriente de los sucesos de la guerra. Está bien informado sobre las batallas en Cambrils, Tarragona, Martorell y, sin duda, sobre la batalla de Montjuïc. Aunque no se puede asegurar que el dramaturgo participara en la batalla de Montjuïc, posee un conocimiento amplio de los detalles, y lo demuestra incorporando esta batalla en la loa y en la comedia. De los sucesos en Tortosa, Cambrils, Tarragona, Martorell y en otras localidades, probablemente se informa gracias a los panfletos que se distribuían durante la contienda. Jaume Romeu, Jaume Matevat y Gabriel Noguers son los impresores catalanes que publicaban la mayoría de panfletos propagandísticos de la guerra, ${ }^{16} \mathrm{y}$ tanto el entremés como la comedia y la loa se imprimieron en el establecimiento del primero. De hecho, sugiero que el autor anónimo pudo haber escrito panfletos de guerra para estos impresores, y, concretamente, para el primero de ellos, Jaume Romeu. ${ }^{17} \mathrm{El}$ estilo de los panfletos propagandísticos y del conjunto dramático del autor anónimo comparten ciertas similitudes. Incluso, La comedia del marqués de los Vélez parecería compuesta por cuatro "relaciones dramáticas" a la manera panfletaria, todas ellas conectadas por una trama ficticia. El autor narra cuatro sucesos históricos - la batalla de Cambrils, la rendición de Tarragona y las batallas de Martorell y de Montjuïc - en los que elimina o reduce el diálogo y los conecta con los episodios ficticios de don Carlos y de doña Leonor, además de los de sus respectivos criados.

La suposición de que el autor anónimo hubiera escrito panfletos de guerra podría relacionarse con el carácter informativo de las tres piezas dramáticas $\mathrm{y}$, asimismo, con su propio anonimato. Los panfletos de guerra y, en particular, las relaciones de Jaume Romeu constituyeron uno de los primeros intentos periodísticos de la península ibérica. Según Henry Ettinghausen, Jaume Romeu ha pasado a la historia como el inventor de las gacetas en la Cataluña de la Guerra dels Segadors. Este impresor barcelonés advertía que sus gacetas imitaban originales franceses enviados cada semana desde París y que permitían al lector acumular un material muy valioso para futuros historiadores (Ettinghausen 918). En las relaciones proto-periodísticas, el nombre del autor deja de tener importancia y casi nunca se incluye. En el prólogo de la comedia, el autor anónimo expresa sus intenciones, opiniones y miedos. Por ejemplo, afirma que escribe solo para entretenerse: "[P]orque nunca los hago [los versos] por oficio, sino por pasatiempo" (fol. 2v); que todo lo que escribe es verdad, "que no hay herejías, sino verdades" (fol. 2v); y que si la comedia llega a España, intentarán quemarla, "y si llegara a Reinos estraños, que un papel suele ir por el aire, en particular si son de la Corona de España, sé que la quemarán" (fol. 2v). Ahora bien: en el prólogo, el autor anónimo no se refiere al anonimato de la pieza y, por lo tanto, deduzco que incluir su nombre no 
tendría importancia para él. Ciertamente, no puedo asegurar que el dramaturgo sea un proto-periodista y que esta sea la razón del anonimato, pero no debe descartarse la hipótesis. Así y todo, una razón posible del anonimato sería el miedo ante cualquier represalia. El anonimato ayudaría a que no tuviera que dar explicaciones, y que no le pasara nada si hubiera un cambio político imprevisto.

El autor anónimo conocía la literatura catalana, los sucesos de la época $\mathrm{y}$, sobre todo, demuestra un buen conocimiento del teatro castellano y de todo aquello que estaba de moda en las obras dramáticas del Barroco. Probablemente, como Francesc Fontanella, el autor anónimo asistía a las representaciones del Teatro del Hospital de la Santa Creu en Barcelona (Miró 236), si bien: "la influència del teatre en castellà no es reduïa a la contemplació de la posta en escena efectiva de les obres, ja que al segle XVII neix també el costum de llegir teatre" ("la influencia del teatro en castellano no se reducía a la contemplación de la puesta en escena efectiva de las obras, ya que en el siglo XVII nace también la costumbre de leer teatro"; Rossich, "El teatre barroc" 57 ). O bien sea por la puesta en escena o bien sea por la lectura, el autor anónimo sabe que el teatro barroco constituye un espectáculo totalizador: "La representación, o conjunto de elementos que formaba el espectáculo que se daba en los corrales, era una suma de géneros distintos entre los que la comedia ocupaba un papel relevante, pero iba acompañada de otros espectáculos que contribuyeron al éxito y aceptación de la misma" (Díez Borque, El teatro 38). En este conjunto totalizador, el propósito del entremés es de complementariedad respecto a la comedia. Si se analiza el espectáculo teatral en su conjunto, coexisten dos mundos opuestos: el idealizado de la comedia y el satírico del entremés (Haverbeck 54). El Entremés de los labradores y los soldados castellanos copia a la perfección el modelo castellano: la burla prevalece y termina con un baile carnavalesco.

El Entremés de los labradores y los soldados castellanos es una pieza breve independiente - tal como lo eran los entremeses castellanos - con su propia trama, pero bien conectada con el conjunto teatral $\mathrm{y}$, específicamente, con la comedia. Si La comedia del marqués de los Vélez se encarga de cuatro "relaciones dramáticas" - Cambrils, Tarragona, Martorell y Montjuïc - y la loa hace un seguimiento de la historia de Cataluña, que acaba con la batalla de Montjuïc, el entremés trata el tema más candente de la Guerra dels Segadors, el alojamiento de los tercios castellanos en Cataluña:

Sembla indubtable que la causa primera de l'aixecament pagès iniciat la primavera de r640 al Vallès i la Selva, i que després s'estengué per altres comarques del Principat, fou la pressió sobre l'economia camperola i els excessos de tota mena que 
comportà l'allotjament dels tercios que tornaven de la campanya de Salses. (Simon i

Tarrés I7)

[Parece indudable que la causa primera del levantamiento de los labradores iniciado en la primavera de ı640 en el Vallés y en la Selva, y que después se esparciría por las otras comarcas del Principado, fue la presión sobre la economía de los labradores y los excesos de toda clase que comportó el alojamiento de los tercios que regresaban de la campaña de Salses.]

Esto es: cada componente de este conjunto dramático - la comedia, la loa y el entremés con el baile - sigue las pautas del teatro barroco castellano. Asimismo, se ocupa de un aspecto concreto relacionado con la Guerra dels Segadors: descripciones de las batallas, la historia de Cataluña hasta llegar a los primeros años de la guerra en la loa $\mathrm{y}$, finalmente, una sátira del alojamiento de los tercios en el entremés y en el baile.

Como expone Félix Lope de Vega (1562-1635), el entremés combina entretenimiento, crítica y sátira:

Para entretener la gente

hago oficio de malilla,

y con una guitarrilla

digo coplas de repente,

motes, apodos, sainetes. (597)

El entremés constituía la pieza teatral más esperada del público y los dramaturgos aprovechaban su popularidad para combinar crítica y sátira. Según Jean Sentaurens, los entremeses y los bailes garantizaban el éxito comercial del espectáculo dramático y "desde el momento en que se prohíben ... en los escenarios de los corrales, se desvanece la clientela" (69). El autor anónimo se sirve tanto de la popularidad de los entremeses como de la combinación crítica-sátira y, de esta manera, incorpora en su conjunto dramático un tema complejo y polémico de la guerra: el alojamiento de los tercios castellanos en Cataluña. Así, la pieza vital del conjunto dramático se conecta con la movilización inicial de los catalanes y con una de las causas principales de la Guerra dels Segadors. Sin duda, incorporar el rechazo a los tercios en el entremés supone una magnífica herramienta propagandística.

Los catalanes reclamaban de las instituciones centrales y locales un posicionamiento que legitimara la expulsión de los tercios. Tal y como apunta Eva Serra: "a nivell popular, es veia amb mals ulls les cauteles vilatanes ... Les viles i ciutats tenien l'ull posat en el que feia Barcelona" ("a nivel popular, se veía con malos ojos las cautelas de las villas ... Las villas y 
ciudades tenían el ojo puesto en lo que hacía Barcelona"; 42). La queja de la poca movilización de Barcelona está muy presente en el entremés:

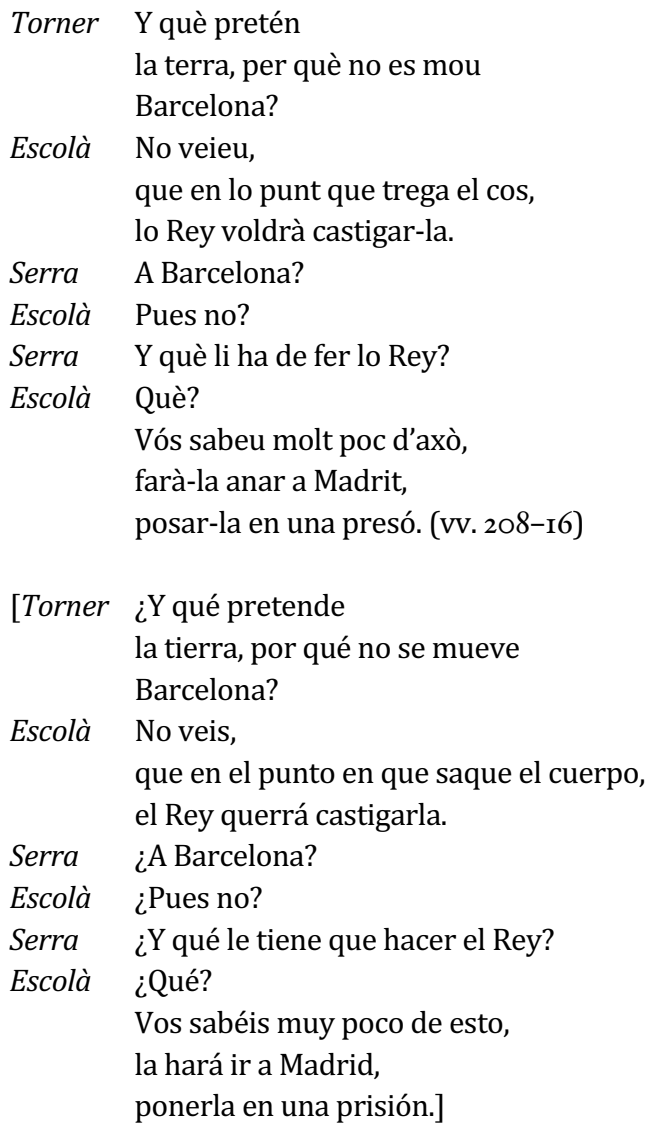

La crítica a la poca actuación aparece en el entremés, pero el dramaturgo también defiende Barcelona con el motivo del posible castigo real. Aunque la acción dramática del Entremés de los labradores y soldados castellanos se sitúa en el campo, el autor anónimo se refiere a Barcelona en más de una ocasión. He aquí un ejemplo: "A on anau soldats de Castella? / A Barcelona, a intimidar-la [amb] la guerra" " ¿Adónde vais soldados de Castilla? / A Barcelona, a intimidarla con la guerra"; vv. 545-46). En la comedia y en la loa es más obvio el conocimiento que el autor anónimo tiene de la ciudad de Barcelona y, en particular, de Montjuïc, que se repite insistentemente. Por esta razón y por la impresión de su obra en el establecimiento de Jaume 
Romeu, concluyo que el autor anónimo era barcelonés o, al menos, vinculado estrechamente con la ciudad de Barcelona.

A pesar de que en el entremés se menciona Barcelona, el autor anónimo abandona la ciudad para trasladarse al campo. La acción dramática de la comedia sigue el avance de Pedro Fajardo (I6O2-47), marqués de los Vélez, por Cataluña y concluye con su derrota en Barcelona. En este avance geográfico, la ciudad de Barcelona se instaura como el centro neurálgico o, mejor dicho, el centro neurálgico se sitúa en la montaña de Montjuïc. Barcelona y Montjuïc siguen como el foco central en la loa. Sin embargo, el recorrido espacial de la comedia pasa a un recorrido histórico en la loa: del reinado de Alfonso II (I157-96) al de Felipe IV (I605-65). No hay ningún tipo de recorrido historiográfico en el entremés y, por ello, se consideraría más local - característica común de los entremeses: "debido a su brevedad, tiende a enmarcarse en una localización única (aldea, corte, venta, mesón) y evita el recorrido por lugares geográficos distantes" (Martínez López 62). Aún más, el carácter local o rural permite al autor anónimo dibujar un cuadro de costumbres - otra característica típica de los entremeses: "parece admitirse por la mayoría de estudiosos del género su carácter costumbrista y un cierto realismo que posibilitaría su utilización como fuente de documentación y como reflejo - directo o invertido - de la realidad que ambienta" (Fernández Oblanca 59). El Entremés de los labradores y soldados castellanos supondría un breve cuadro rural en el que se dramatiza satíricamente el alojamiento de los tercios castellanos en las casas de labradores catalanes. Este cuadro que pinta el autor anónimo contiene algunos rasgos realistas, pero no es un reflejo de la Cataluña de la Guerra dels Segadors. Al contrario, ahí se incluyen tipos y elementos cotidianos para, seguidamente, distorsionarlos con el fin de crear, así, un cuadro jocoso: "un cierto costumbrismo en cuanto reflejo de costumbres y tipos cotidianos, pero estoy totalmente convencido de la exageración que supondría considerar el entremés como un reflejo exacto de la vida de cada día" (Díez Borque, Sociedad 277-78). ${ }^{18}$

Cinco son las características básicas del cuadro dramático que dibuja el autor anónimo. La primera es situar la pieza en una aldea o en un pueblo. La localización del Entremés de los labradores y soldados castellanos es inexacta, pudiendo ubicarse en cualquier pueblo de Cataluña, si bien en un lugar donde se alojaran los soldados castellanos. La segunda sería emplazar toda la acción en la casa del labrador Torner, y, así pues, se ofrece un ambiente familiar que modera el enfrentamiento violento entre labradores y soldados. La tercera es situar el conflicto concretamente en la cocina: espacio incluso más familiar. Además, y en cuarto lugar, sería el tema de la disputa: la comida que se sirve a los soldados en casa de Torner. Hasta que 
el soldado Traguillos abandona la casa y Dominga va en busca de refuerzos para ayudar a su esposo, todo el diálogo gira en torno a la comida: "yo he de comer cebollas, vil canalla" (v. 2). Al ambiente familiar que ofrece la casa, la cocina y la comida, se le añade la quinta característica: el vocabulario de plantas y de animales, detalle que ayuda a recrear un tono campesino en contraposición a los soldados corruptos de la Corte, "que en regiones, árboles, ni plantas, / no queden para hacer otra vez nido" (vv. I05-06) y "una gallina, / algún polluelo, algún pichón ... un águila me trayga coronada" (vv. 92-IO2). Además, no hay que olvidar que los castellanos son representados por soldados, mientras los catalanes por labradores.

Ahora bien, el cuadro dramático con las cinco características básicas se distorsiona. El dramaturgo ejecuta y consigue esa distorsión con el humor y con el baile carnavalesco final - que además es un baile folclórico: una sardana. La comicidad aparece de principio a final en el entremés y se incorpora, sobre todo, con la falta de comunicación entre catalanes y castellanos: "El huésped no me ha entendido" (v. 287). Esta falta de comunicación lleva a todo un juego de palabras: "y pues fan capitans a trochemoche. / Querrá el villano que me desabroche" ("y pues hacen capitanes a trochemoche"; vv. 38-39). Aunque hay desacuerdo entre los catalanes y los castellanos, el humor permite que la tensión se suavice. El enfrentamiento entre ambos grupos es patente - los dos llevan armas, están a punto de matarse y se intenta cometer una violación - pero en ningún momento el público o el lector siente miedo por los personajes, ni tampoco se pierde el humor. Uno de los soldados castellanos expone con claridad la función del humor: "Dios que gasta lindo humor" (v. 278). Es más, el humor se impone con la sardana final y con el baile de Traguillos con los cuernos puestos. Cabe señalar que una de las palabras más repetidas en el entremés es "cuernos" y sus derivados, e incluso se traduce a cinco idiomas:

En castellà es diuen

cuernos, y en italià,

le corna, en francès

cornes, en irlandès

horns, y en flamenc ... (vv. 427-3I)

[En castellano se dicen

cuernos, y en italiano,

le corna, en francés

cornes, en irlandés

horns, y en flamenco ... ] 
El humor y situar la pieza en una casa con dos tipos de personajes en conflicto conecta el Entremés de los labradores y soldados castellanos con los entremeses castellanos. La casa de Torner con los labradores y con los soldados recordaría, en cierta manera, la típica venta en la que se encuentran individuos, también, en conflicto.19 Sin duda, el dramaturgo conoce bien el teatro de la época e, incluso, llama a la esposa del protagonista catalán Dominga - nombre típico en los entremeses - y al protagonista castellano Traguillos, también un nombre que recuerda los entremeses castellanos: "El nombre se construye según un mecanismo de asociación y adecuación que, por medio de la connotación, pretende ajustarse a aquello que designa. Los nombres propios de uso corriente más frecuente ... son para las figuras femeninas los de Juana y María, ... Clara, ... Catalina, Tomasa, Inés, ... Francisca, Lucía, Luisa, Teresa, ... Isabel, Aldonza, Quiteria, Beatriz, ... Dominga ..." (Martínez López I42).20

El dramaturgo se vale de su conocimiento del teatro castellano para incorporar su característico humor y ambiente con el deseado fin de crear un entremés de carácter político. Es decir, sigue la misma línea propagandística de la comedia y de la loa. Pongo por caso y a modo de ejemplo el repetido odio al conde duque de Olivares, Gaspar de Guzmán y Pimentel (1587-I645), y la constante aversión al protonotario Jerónimo de Villanueva (1594-I653):

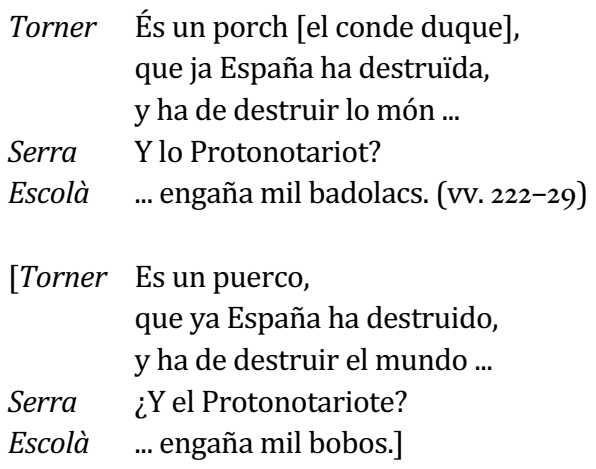

El Entremés de los labradores y soldados castellanos es el único entremés bilingüe, de carácter político e histórico de la época. Aunque abandona las batallas de Cambrils, de Tarragona y de Martorell - incluidas en la comedia - el entremés trata uno de los sucesos más determinantes de la Guerra dels Segadors: la campaña militar de Salses, considerada por Manel Güell "el punt d'inflexió decisiu en el camí a la revolta antimonàrquica" ("el punto de inflexión decisivo en el camino a la revuelta antimonárquica"; 193) , y por 
John H. Elliott "la aceleración del deterioro de las relaciones entre el Principado y la corte ... [la caída de Salses] se había convertido realmente en la señal para las recriminaciones generales" (372). El entremés, entonces, se relaciona con el esfuerzo desmesurado del asedio de Salses, en el que murieron centenares de hombres y, sobre todo, con la movilización de soldados a la frontera francesa que requerían alojamiento. Francisco Manuel de Melo (1608-66) aseguraba que Cataluña agrupó el ejército más numeroso que España había formado jamás dentro de su propio territorio. Mientras la cifra de Melo es de treinta mil hombres (24), el virrey Santa Coloma (1593-I640) declaraba, en una carta dirigida al conde duque de Olivares, que los catalanes habían sustentado a "más de veinte y cinco mil hombres" (Tormé i Liori 85). Así pues, la comedia incorpora detalles del recorrido del marqués de los Vélez por el sur de Cataluña hasta llegar a Barcelona, donde sería derrotado. En cambio, el entremés incorpora detalles del norte de Cataluña. Traguillos representaría a un soldado castellano alojado cerca de la frontera con Francia y participante en el asedio a Salses: "En Salsas la gané, porque a un francés / le derribé una espada de un revés" (vv. 44-45).

A partir de un caso concreto y ficticio - el alojamiento de Traguillos en casa del labrador Torner - el dramaturgo informa sobre la situación de los soldados en Cataluña, cuyo número calcula "de vint mil que s'allotgen / per Cathaluña, sé jo" ("de veinte mil que se alojan / por Cataluña, sé yo"; vv. 20405). El entremés explica las obligaciones de los catalanes hacia los soldados que se hospedaban en sus casas: "la Constitució de Cathaluña obliga / a que li don menjar honradament" "la Constitución de Cataluña obliga / a que se le dé comida honradamente"; vv. 71-72). También, expone los abusos de los soldados, quienes robaban "que robaren lo castell" ("que robaron el castillo"; v. I88); quemaban casas e iglesias, "que cremaren ab rigor / los Sants" ("que quemaron con rigor / los Santos"; vv. I89-90); violaban mujeres, "gozaréysla vive Dios, / y aun encima del marido" (vv. 38o-8I); y mataban animales, "un d'aquestos soldadots / matà totas las gallinas" ("uno de estos soldadotes / mató todas las gallinas"; vv. I46-47). Son los mismos crímenes que se contaban reiteradamente en las crónicas y en los dietarios de la época:

El Dr. Pere Coderch proposa el sacrilegi i el crim detestable comès pels soldats del terç de D. Leonardo Moles ... , els quals, després d'atacar els vilatans i de robar i incendiar les cases, van irrompre per la força en l'església parroquial de Sant Martí de Riudarenes, robant i destruint no sols els béns que hi guardava la gent, sinó també els vasos sagrats, calzes sacerdotals, ornaments, almoines de les confraries i pels 
sufragis dels difunts, i després com si fossin bàrbars i infidels, van calar foc a dita església. (Busquets Dalmau 39I)

[El Dr. Pere Coderch propone el sacrilegio y el crimen detestable cometido por los soldados del tercio de D. Leonardo Moles ... , los cuales, después de atacar a los aldeanos y de robar y de incendiar las casas, irrumpieron por la fuerza en la iglesia parroquial de San Martín de Riudarenes, robando y destruyendo no solo los bienes que guardaba la gente, sino también los vasos sagrados, ropa sacerdotal, ornamentos, limosnas de las cofradías y para los sufragios de los difuntos, y después como si fueran bárbaros e infieles, calaron fuego a dicha iglesia.]

Aunque hay personajes históricos - Felipe IV, Olivares y Villanueva, entre otros - y sucesos históricos - las escaramuzas en Salses; en Montjuïc, "Montjuïc alt vos saluda" ("Montjuïc alto os saluda"; v. 523); y en Holanda, "En Olanda, sabéys que tierra es esa" (v. 62), entre otras - el entremés es ficticio y general. El autor anónimo escoge un lugar, pero no le pone nombre ni lo describe. Ese nombre poco importa ya que la brevedad del entremés no da para descripciones. Los personajes tampoco son descritos, más bien se reducen a arquetipos. Entre aquellos representativos de los entremeses, se encuentran el viejo, el bobo, el sacristán, el rufián, el vizcaíno, la celestina, la meretriz, la criada, la joven mal casada y, por supuesto, el soldado (Maestro 543). El autor anónimo incorpora al soldado malicioso como representante de los castellanos y al labrador sencillo como representante de los catalanes. Los personajes del entremés se retratan a partir de estereotipos. Los catalanes se asocian con el trabajo - Torner significa tornero - o con bandoleros - Perot y Serra recuerdan a Perot Rocaguinarda (1582-1635), el bandolero histórico que Miguel de Cervantes (1547-1616) incluyó en la segunda parte del Quijote (1615), y a Serrallonga (1594-1634), otro bandolero histórico al que Antonio Coello (I6II-52), Francisco de Rojas Zorrilla (1607-48) y Luis Vélez de Guevara (I579-I644) dedicaron su comedia titulada El catalán Serrallonga (I636). La conexión entre Perot y Serra con los bandoleros es inevitable: “'bandolers' d'ahir van ser els segadors de després i els almogàvers o miquelets de més tard; és a dir, la base social del soldat català del segle XVII" ("'bandoleros' de ayer fueron los segadores de después y los almogávares o miqueletes de más tarde; es decir, la base social del soldado catalán del siglo XVII"; Serra I4I). No solo los nombres de los personajes catalanes se asocian con el trabajo y con la valentía, sino que también sus acciones y sus palabras: “que jo me'n tinc d'anar a treballar" ("que yo me tengo que ir a trabajar "; v. 69) y "cuatro soldados del Rey. / Només de quatre, axò és poc" ("Solo de cuatro, eso es poco"; vv. 263-64). 
Si los catalanes son trabajadores y valientes, los castellanos son perezosos y cobardes: "després que farts com uns porchs / tras las tàpias tot lo dia / estenen la pancha al sol" ("después que llenos como unos puercos / tras las tapias todo el día / extienden la panza al sol"; vv. 158-60) y "A lo covard!" (“iAy el cobarde!”; v. I23) Aparte de Traguillos, los otros soldados castellanos no tienen nombre y se diferencian solo por un número: Soldado I, Soldado 2 y Soldado 3. Ahora bien, la ebriedad, que otorga el nombre a Traguillos, se extiende a todos los castellanos: "borracho pretén / venjar-se de son temor" ("borracho pretende / vengarse de su temor"; vv. I29-30). Además de borrachos, de perezosos y de cobardes, Traguillos y los otros soldados son arrogantes, "d'aquesta arrogant nació" ("de esta arrogante nación"; v. I40); fanfarrones, "un castellà fanfarró" ("un castellano fanfarrón"; v. I64); mentirosos, "però no dirà una veritat" ("pero no dirá una verdad"; v. 35); y aprovechados: "Barcelona la rica quan bien pareces, / con tus muros y torres y chapiteles. / Mas si el Conde Duque te puede pescar, / tan igual te ha de hazer como tu arenal" (vv. 236-39). Los estereotipos y las generalizaciones forman parte de la comicidad del entremés. Sirva como ejemplo de esta comicidad el momento en que Torner le pregunta el nombre completo a Traguillos: "Don Fernando de Cárdenas y Luna, / Leyva, Manrique, Osuna / ... eso solo es por mi padre, / Ramírez y Alvarado por la madre" (vv. 78-8I). Los "guzmanes" - nombre que utiliza el dramaturgo para referirse a los castellanos - son ridiculizados de principio a fin, y la sátira alcanza su cenit cuando Traguillos baila con los cuernos puestos.

A diferencia de los entremeses primitivos, que se caracterizaban por su final en palos, los entremeses del siglo XVII terminan en bailes (Madroñal I60). Tirso de Molina (1579-I648) advertía el cambio, "¿Qué entremeses habrá escrito? / Al pie de trescientos / ¿Tantos? / Y acaban en bailes todos / si los antiguos en palos" (vv. 1352-56). Y, según Luciano García Lorenzo, inicia esta práctica Cervantes, quien se da cuenta de que los bailes gustan más que los aporreamientos (I49): "Débesme muchos regalos, / huésped, si bien lo supieses: / yo quité a los entremeses / que no acabasen en palos". ${ }^{21}$ El nuevo baile final provoca alegría y la sensación barroca que el orden se ha restablecido. Se trataba de una celebración o una fiesta popular que animaba al público, tal y como lo expresa Agustín Moreto (I6I8-69): "Pues por celebrar la burla / remátese con un baile / ... / Que con fiestas y gustos hoy se celebre" (vv. 208-I3). El bayle al uso de Cathalunya es la celebración final o una especie de reconciliación entre catalanes y castellanos. Todos catalanes y castellanos - están contentos y el orden parece restablecido. No obstante, este baile - o breve tregua - no tiene nada de inocente. El baile es una sardana, y eso ya proyecta connotaciones políticas. Por un lado, el 
Entremés de los labradores y los soldados constituiría una batalla dialéctica - con espadas y con pistolas - entre catalanes y castellanos, con una clara victoria catalana. Por otro lado, el bayle al uso de Cathalunya constituiría la celebración de la victoria o la sublimación de los catalanes. Dicho baile victorioso se equipararía al triunfo de Montjuïc del 26 de enero de i64r. El autor anónimo conecta el triunfo en la casa de Torner con el triunfo en la montaña de Montjuïc: "Montjuïc alt vos saluda, / y faja a Castella bañas" ("Montjuïc alto os saluda, / y haga a Castilla cuernos"; vv. 523-24). ${ }^{22} \mathrm{El}$ entremés finaliza con un baile en el que se castiga a Traguillos, representante de los castellanos: "En ocasiones el castigo es el esperado porque el entremés pertenece a una familia folklórica reconocible, sintetizada en el refrán ... 'cornudo apaleado, mandadle que baile o mandadle bailar'” (Lobato 58).

El Entremés de los labradores y soldados castellanos probablemente nunca llegó a representarse. ${ }^{23}$ De todas formas, constituye una pieza teatral de indudable valor histórico y documental sobre la Guerra de Cataluña. Formaría parte del variado y del diverso espectáculo barroco. Su función consiste en un juego escénico no falto de comicidad o, en palabras de Fernando Lázaro Carreter, en un "pasaje con personajes populares y de tono preferentemente humorístico, que aparece en principio o en medio de una obra de carácter serio" (88). De manera sencilla y graciosa, el Entremés de los labradores y soldados castellanos informa sobre un tema polémico: el alojamiento de los tercios castellanos en Cataluña. Como sucede con dos obras posteriores estudiadas por Kenneth Brown, Loa para la Comedia de los Juegos Olímpicos (1703) y Poema armónico que se cantó, en aplauso de un natalicio (1703), el Entremés de los labradores y soldados castellanos contiene un discurso ingenioso y provoca admiración por el mensaje de máxima catalanización (I4I). Asimismo, sigue a la perfección los preceptos del teatro castellano de la época - brevedad, presentación rápida de los personajes, tono humorístico - sin olvidar, en ningún momento, que se trata de una obra de carácter político, en la que se alaba a los catalanes y se condena a los castellanos. Esto es: el bilingüismo, el mensaje político y el tono humorístico se fusionan ingeniosamente, para dar paso a una creatividad que es la base de la agudeza barroca (Solervicens I4). La combinación soldados-labradores también implica esa misma fusión ingeniosa. A pesar del conflicto armado, la Guerra dels Segadors evoca un ambiente campestre con unos segadors catalanes que luchan en defensa de su tierra. El entremés sugiere el mismo ambiente bucólico con labradores 
catalanes trabajadores y valientes que se protegen de los agravios de las fuerzas de ocupación castellanas.

University of Wyoming

NOTAS

I Para más información sobre la Proclamación Católica a la Magestad Piadosa de Filipe el Grande, véase el estudio introductorio de la obra realizado por Antoni Simon i Tarrés y Karsten Neumann.

2 Para más información sobre el Aristarco o censura de la Proclamación Católica de los catalanes, véase el capítulo de María Soledad Arredondo sobre la obra.

3 Véanse La rebelión de Barcelona ni es por el güevo ni es por el fuero (I64I) de Quevedo y Cataluña desengañada (I646) de Ros.

4 Véanse Manifiesto de la fidelidad catalana, integridad francesa y perversidad enemiga de la justa conversación de Cataluña en Francia (I64I) de Martí i Viladamor, y Catalana justicia contra castellanas armas (I64I) de Font.

5 Véase Plecs poètics catalans del segle XVII de la Biblioteca de Catalunya de Joana Escobedo.

6 Véanse Amor, firmesa i porfia (edición conjunta con Joan Ramis i Ramis) y Lo Desengany. Sobre las fechas inexactas de nacimiento y de muerte de Fontanella, véanse "Mudats tots los perfils: Aportacions a la biografia de Francesc Fontanella" de Pep Valsalobre, y "La mort de Francesc Fontanella: A propòsit d'una falsa atribució" de Albert Rossich.

7 Después de ofrecer el título largo y completo de las obras, escribiré una versión abreviada. Además, he editado la transcripción de los textos modernización, separación de palabras, puntuación y acentuación - tanto en catalán como en castellano para facilitar el acceso de las obras antiguas al lector. Albert Rossich y Jordi Cornellà expresan su preocupación de editar textos polilingües o mixtilingües (52). Me sumo a su preocupación y, como ellos, opto por respetar escrupulosamente el texto.

8 No se conocen las fechas de composición de Amor, firmesa i porfia ni de $L o$ Desengany de Fontanella. Para más información sobre cuál de las dos obras podría haberse escrito primero, véase "Mitologia burlesca, invenció barroca i catarsi: L'ànima frondosa de Fontanella o notes disperses a Lo Desengany" de Pep Valsalobre.

9 Las primeras palabras de La comedia del marqués de los Vélez rezan "A quien quisiera leer la comedia" (fol. 2v).

IO Para más información sobre La comedia del marqués de los Vélez y sobre la Loa de la comedia de Montjuïc, véanse "La comedia del marqués de los Vélez: El abandono de la Corte y la llegada a Montjuïc" y "Loa de la comedia de Montjuïc: Un diàleg bèl-lic entre Catalunya i Castella" de Conxita Domènech.

II El entremés y el baile están documentados en la base de datos Iberian Books, y considerados "bibliographical ghost": iberian.ucd.ie/view/iberian:64329. Hay 
una versión manuscrita del entremés y del baile en el Arxiu Històric de la Ciutat de Barcelona (ms. B-I50). Esta versión manuscrita se puede consultar en línea:

wi5r.bcn.cat/opac/doc?q=Entrem $\% \mathrm{C}_{3} \% \mathrm{~A} 9 \mathrm{~s}+\mathrm{de}+\mathrm{los}+$ labradores+y+soldados+ castellanos\&start=o\&rows=I\&sort=msstored_fld $8 \mathrm{I} \% 20$ asc\&fq=mssearch_doct ype \&fv $=* \& f q=$ media\&fv $=*$.

I2 Albert Rossich y Jordi Cornellà señalan que el anticastellanismo de la comedia no se transmite a través de la lengua sino por el contenido (I47).

I3 La lección de lengua catalana que imparte la criada Aminta al criado Doblón es extraordinaria: "Parla ja català: / per dir la mano, hauràs de dir la mà; / pa y vi, aquexas cosas ja las saps; / per dir los nabos, has de dir los naps; / las lechugas, lletugas; / per dir arrugas, has de dir sols rugas; / y, en fi, lleva als vocables una lletra, / que axí la cathalana llengua se penetra" ("Habla ya catalán: / para decir la mano, habrás de decir la mà; / pan y vino, estas cosas ya las sabes; / para decir los nabos, has de decir los naps; / las lechugas, lletugas; / para decir arrugas, has de decir solo rugas; / y, en fin, quita a los vocablos una letra, / que así la catalana lengua se penetra"; vv. III2-I9).

I4 Según Magí Sunyer, en el imaginario romántico, el almogávar se convierte en sinónimo de patriota, "de defensor o lluitador per la terra" ("de defensor o luchador por la tierra”; I099). En La comedia del marqués de los Vélez, el almogávar aparece como patriota.

I5 Todas las traducciones del catalán al castellano son mías.

I6 Los tres impresores son de Barcelona. En otras ciudades catalanas había otros impresores, pero, como afirma Eulàlia Miralles, la publicación de propaganda impresa fuera de Barcelona fue mínima (I9I).

I7 El diseño y los grabados de la portada de La comedia del marqués de los Vélez y de Relació en rima de Jaume Roig, de tot lo que ha succeït dintre i fora de Perpinyà (1642) son idénticos. Y, ciertamente, los dos fueron impresos por Jaume Romeu. Ahora bien: esto no quiere decir que los dos textos fueron escritos por una misma persona. Con frecuencia, los grabados de la portada se repetían con el fin de reducir el costo de impresión.

I8 A pesar de que el costumbrismo se asocia con la primera mitad del siglo XIX, no considero anacrónico afirmar que el Entremés de los labradores y soldados castellanos es un cuadro breve en el que se dramatiza satíricamente el alojamiento de los tercios castellanos en Cataluña. Al costumbrismo se le han admitido unas raíces que se remontan a los orígenes de la literatura con escritores como el Arcipreste de Talavera (circa I398-I470) u obras como La Celestina (circa I498): “Los estudios de Correa Calderón, Margarita Ucelay Da Cal, José Luis Varela, etc., analizan los orígenes del costumbrismo español desde esta perspectiva. Significativa es al respecto la magna antología del costumbrismo español realizada por Correa Calderón al incluir en el inicio de su obra el cuadro cervantino Rinconete y Cortadillo ... Se podría apuntar, pues, que el costumbrismo ofrece piezas representativas del siglo XVII" (Ortiz García y Sánchez Gómez 234). 
I9 Un ejemplo sería el entremés titulado La venta (I635) de Quevedo: "gracioso cuadro costumbrista que se desarrolla en una venta de camino, ambiente que se encuentra en otros entremeses" (Arrellano y García Valdés 347).

20 Una práctica común en los entremeses era que el nombre sugiriera una característica física o propia del personaje. Esto se observa perfectamente en los entremeses de Cervantes: "[Los personajes] son individualmente caracterizados con nombres propios a la manera de apodos o motes. Panduro, Algarroba, Humillos, Jarrete, Berrocal, Rana, Pesuña y Estornudo, que, en cada caso, sirven para identificar y caracterizar de algún modo el personaje respectivo. Los motes de los regidores, Algarroba y Panduro, apuntan a una devaluación del personaje" (Castilla 29).

2I Estos versos pertenecen a un epitafio de Alonso Jerónimo de Salas Barbadillo (1580-1635). Dicho epitafio, escrito hacia I6r8, va dirigido "a un poeta entremesero" y es muy probable que se refiera a Cervantes, quien había muerto hacía poco. Émile Arnaud compiló los epitafios y las seguidillas de Salas Barbadillo.

22 La comedia concluye con la victoria catalana en la batalla de Montjuïc. La victoria en Montjuïc ya se anticipa en la loa: "mira sobre Montjuïc, monte eminente, / hechos corderos tus leones fieros" (fol. $7 \mathrm{v}$ ).

23 No se tiene constancia de que la obra se representara. Incluso, en la comedia, el autor anónimo duda que la obra se escenifique: "que no habrá quien me la silbe en teatros" (fol. 2v).

OBRAS CITADAS

ARnAu D, Ém ILe. “Epitafios y seguidillas de Alonso Salas Barbadillo.” Criticón 4 (I98I): $5^{-42}$.

A RR E D N D , MAR ÍA S L E D AD. "El Aristarco o censura de la Proclamación Católica de los catalanes, de Francisco de Rioja." Literatura y propaganda en tiempos de Quevedo: Guerras y plumas contra Francia, Cataluña y Portugal. Madrid: Iberoamericana, 2OII. 239-48.

arrellano, ignacio, y Celsa c. García valdés. "El Entremés de la venta, de Quevedo." La Perinola io (2006): 345-60.

B o own, кenneth. "Nou versos d'Antoni de Peguera i Aimeric: El Poema armónico que se cantó, en aplauso de un natalicio." Bulletí de la Reial Acadèmia de Bones Lletres de Barcelona LIII (2OII-12): 123-80.

Bus que ts dalmau, jo an. La Catalunya del Barroc vista des de Girona. La crònica de Jeroni de Real (I626-I683). Barcelona: Publicacions de l'Abadia de Montserrat, I994.

Castilla, A b B t o, E D. Entremeses. Miguel de Cervantes Saavedra. Madrid: Akal, 2007.

Dí E z B Rque, José ma Rí a. Sociedad y teatro en la España de Lope de Vega.

Barcelona: Antoni Bosch, 1978. 
—. El teatro en el siglo XVII. Madrid: Taurus, 1988.

D o M ÈnECH, CONXIt A. “La comedia del marqués de los Vélez: El abandono de la

Corte y la llegada a Montjuïc." La Guerra dels Segadors en comedias y en

panfletos ibéricos: Una historia contada a dos voces (1640-1652). Kassel:

Reichenberger, 2016. 100-42.

—. "Loa de la comedia de Montjuïc: Un diàleg bèl-lic entre Catalunya i Castella."

Caplletra 60 (2016): 15-29.

E Ll Iо T T, Jо H н н. La rebelión de los catalanes: Un estudio sobre la decadencia de

España 1598-I640. Trad. Rafael Sánchez Mantero. Madrid: Siglo XXI, 2014.

"Entremés". Diccionario de autoridades. 3 vols. Madrid: Gredos, 1963.

Entremés de los labradores y soldados castellanos, con un bayle al uso de Cathalunya.

Barcelona: Jaume Romeu, I64I.

E SC O B D 0, Jo A A, ED. Plecs poètics catalans del segle XVII de la Biblioteca de

Catalunya. Barcelona: Biblioteca de Catalunya, 1988.

E T T I n G H A U SE N, h E n Ry. "La Guerra dels Segadors y la prensa." Actas del X Congreso

de la Asociación Internacional de Hispanistas. Vol. 2. Ed. Antonio Vilanova.

Barcelona: Publicaciones Universitarias, 1989. 915-20.

La famosa comedia de la entrada del marqués de los Vélez en Cathaluña, rota de las tropas castellanas y assalto de Montjuïc. Barcelona: Jaume Romeu, I64I.

F ER NÁ N DE Z O B L AN C A, J U S T o. Literatura y sociedad en los entremeses del siglo XVII.

Oviedo: Universidad de Oviedo, 1992.

F O N T, J O SE P. Catalana justicia contra las castellanas armas. Barcelona: Jaume

Matevat, I64I.

F O T AN ELla, FR AN C ESC. Lo desengany. Ed. Anna M. Torrent. Barcelona: Edicions 62, I968.

FOnTANELla, FRAnCESC, y JOAn RAmis i Ramis. Francesc Fontanella i Joan Ramis $i$

Ramis. Teatre barroc i neoclàssic. Eds. Maria Mercè Miró y Jordi Carbonell.

Barcelona: Edicions 62, 1982.

GARCíA L ORENZO, L UCIAN o. La construcción de un personaje: El gracioso. Madrid:

Fundamentos, 2005.

G Ü E LL, M AN E L. Camí a la revolta (I625-I640). Lleida: U de Lleida, 2008.

HA VERBECK, ERWIN. “Origen y características del entremés.” Documentos

Lingüísticos y Literarios II (1985): 53-60.

LÁzaro CARRETER, FER NAN D o. Diccionario de términos filológicos. Madrid: Gredos,

I953.

Loa de la comedia de Montjuïc. Barcelona: Jaume Romeu, I64I.

L O B A T o, ma Ría luisa, E D. Loas, entremeses y bailes de Agustín Moreto. Vol. I.

Kassel: Reichenberger, 2003 .

MADRO ÑAL, ABRAHAM. "El entremés en la época de Felipe II y su relación con el

entremés barroco." El teatro en tiempos de Felipe II. Eds. Felipe B. Pedraza Jiménez y

Rafael González Cañal. Cuenca: U de Castilla-La Mancha, I999. I37-62. 
MAESTR 0, JE Sú S G. “Arte barroco y personaje literario.” Barroco. Ed. Pedro Aullón de Haro. Madrid: Verbum, 2004. 52I-66.

MARTí I VILADAMOR, F R ANCESC. Manifiesto de la fidelidad catalana, integridad francesa y perversidad enemiga de la justa conversación de Cataluña en Francia. Antwerp: n.p., I646.

MARTíne Z Ló PE Z, maRía José. El entremés: Radiografía de un género. Toulouse: Presses Universitaires du Mirail, 1997.

melo, FRAn Cis co man UE L De. Guerra de Cataluña. Barcelona: Seix Barral, 1969.

MIRALLES, EULÀLIA. "Els escriptors catalans en una Europa en conflicte: La propaganda política impresa de la Guerra dels Segadors." Caplletra 52 (2OI2): I8I-205.

MIRÓ, MARIA MERCĖ. “Circe i Proteu en el teatre de Francesc Fontanella o la innovació barroca en l'efímer de l'espai escènic." Actes del Vuitè Col·loqui Internacional de Llengua i Literatura Catalanes. Eds. Antoni M. Badia i Margarit y Michel Camprubí. Barcelona: Publicacions de l'Abadia de Montserrat, 1989. 235-46.

molina, tirso De. Comedias de Tirso de Molina. Ed. Emilio Cotarelo y Mori. Madrid: Nueva Biblioteca de Autores Españoles, I907.

M ORET O, A G USTín. Entremés famoso del poeta. Barcelona: Linkgua Ediciones, 2009.

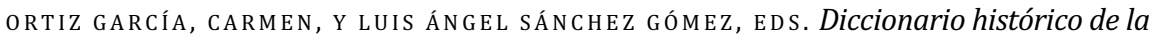
antropología española. Madrid: Consejo Superior de Investigaciones Científicas, I994.

QUEVED Y Y VILlegas, Francisco de. La rebelión de Barcelona ni es por el güevo ni es por el fuero. Obras completas. Ed. Aureliano Fernández-Guerra y Orbe. Madrid: Rivadeneyra, I852. 28I-86.

Ros, A LeXANd Re De. Cataluña desengañada. Nápoles: E. Longo, I646.

R OSSICH, ALBERT. "La mort de Francesc Fontanella: A propòsit d'una falsa atribució." Revue d'Études Catalanes 4 (200I): 87-Ioo.

—. "El teatre barroc (segle XVII)". El teatre català dels orígens al segle XVIII. Eds. Albert Rossich, Antoni Serrà Campins y Pep Valsalobre. Kassel: Reichenberger, 2OOI. 57-79.

R OSS ICH, AL B ER T, Y J R D I COR N L LÀ. El plurilingüisme en la literatura catalana: Retòrica, versemblança, diglòssia. Bellcaire d'Empordà: Vitel•la, $20 \mathrm{I} 4$.

SENTAURENS, JEAN. "Bailes y entremeses en los escenarios teatrales sevillanos de los siglos XVI y XVII: ¿Géneros menores para un público popular?” El teatro menor en España a partir del siglo XVI. Ed. Luciano García Lorenzo. Madrid: Consejo Superior de Investigaciones Científicas, 1983.67-87.

SER RA, Eva. "Catalunya el I640." Pedralbes. Revista d'Història Moderna I5 (1995): 137-50. Simon i t ARRÉs, An to ni. Cròniques de la Guerra dels Segadors. Barcelona: Curial, 2003.

SIMON I TARRÉS, ANTONI, Y KARSTEN NEUMANn. Introducción. Proclamación Católica a la Magestad Piadosa de Filipe el Grande. Barcelona: Base, 2003. 
SOLERVIC ENS. J OSEP. Introducció. La poètica barroca a Europa: Un nou sistema epistemològic i estètic. Eds. Antoni L. Moll y Josep Solervicens. Barcelona: Punctum, 2009. 7-2I.

SUNYER, MA Gí. "Mitologia romàntica: Els almogàvers en la poesia del segle XIX." Professor Joaquim Molas: Memòria, escriptura, història. Vol. 2. Barcelona: U de Barcelona, 2003. I095-II4.

TOR M E I LIOR I, AL B E R T E. Misceláneos históricos y políticos sobre la Guerra de Cataluña desde el año M.DC.XXX.IX. Esparreguera: Font-Rosada, I889.

VALSA LOB RE, PEP. "Mitologia burlesca, invenció barroca i catarsi: L'ànima frondosa de Fontanella o notes disperses a Lo Desengany." Francesc Fontanella: Una obra, una vida, un temps. Ed. Pep Valsalobre y Gabriel Sansano. Bellcaire d'Empordà: Vitel·la, 2006. 28I-3I8.

—. "Mudats tots los perfils: Aportacions a la biografia de Francesc Fontanella." Els Marges 92 (2010): 54-8I.

VEGA, LOPE DE. Obras. Ed. Marcelino Menéndez Pelayo. Madrid: La Real Academia Española, I892. 